\title{
An Empirical Analysis of the Impact of Interest Rate on Agriculture in Nigeria
}

\author{
Abubakar Sadiq Iliyasu ${ }^{1,2 *}$ \\ 1.University of Greenwich, Old Royal Navy College, Park Row, London SE10 9LS, UK. \\ 2.SEGi College, USJ 1, 47600 Subang Jaya, Selangor, Malaysia
}

\begin{abstract}
This study using regression analysis tried to find connection between lending interest rate and agricultural sector activity in Nigeria for real and nominal values from the beginning of the fourth and current republic (1999) to 2016. Tests showed that interest rate had a strong significant negative relationship with agricultural sector activity. Because interest rate and monetary policy is currently not the main tool used by the federal government to improve this sector this recommended more favorable lending interest rates for farmers and industries to be used in sync with government spending in the agricultural sector as an effective way of improving its performance.
\end{abstract}

Keywords: Interest Rate, Agriculture, Crops, Livestock, Forestry, Fishing, Monetary Policy, Nigeria, Africa.

DOI: $10.7176 / J E S D / 10-22-19$

Publication date: November $30^{\text {th }} 2019$

Acknowledgement

Firstly, I would like to acknowledge the pivotal role of my supervisor Mr. Nizar Ali Khan and my lecturer Mr. Cai Yunchao in conducting this study. I would also like to express my gratitude to SEGi College and the University of Greenwich for facilitating this research.

\section{Introduction}

Nigeria's economy is almost solely reliant on the oil sector. This has made it prone to fluctuations depending on oil prices and was recently plunged into a recession due to falling oil prices. This has highlighted the need for diversification of the economy, the most obvious of ways being to revive its promising but underperforming sector. Fiscal and monetary has been applied to achieve this goal but with little result and it is important to understand why this sector remains in its ailing state.

Monetary policy refers to a central bank or federal reserves' control of interest rate by using money supply and vice versa. This is achieved through changing interest rates, selling or buying government bonds or changing the reserve ratio. Like fiscal policy, it can either be expansionary or contractionary. Expansionary monetary policy seeks to boost money supply to increase consumption, encourage borrowing and investment and reduce unemployment to fuel economic growth. Contractionary monetary policy is usually used to reduce inflation in an economy and is done by reducing money supply. Though a certain level of inflation is healthy and necessary in a growing economy, when it exceeds this level it can cause lower demand in an economy which stunts economic growth and causes unemployment. This is why the central bank uses contractionary monetary policy.

Monetary policy in Nigeria is officially handled by the Central Bank of Nigeria (CBN). They control money supply, set interest rates, control exchange and conduct all other actions that constitute monetary policy. Like all other apex banks, policies are motivated by a host of short term and long-term objectives and goals. Over the years, policies were primarily aimed at achieving external and internal balance of payments however these objectives and the mechanisms used to achieve them have been altered. Two important junctures marked Nigeria's quest for prime monetary policy; the phase before 1986 which was focused on monetary controls and the phase after 1986 which was reliant on market mechanisms.

Currently, Benchmark interest rate/Monetary Policy Rate (MPR) is set at 14\%, statutory liquidity ratio (SLR) at $30 \%$ and cash reserve ratio (CRR) at $22.5 \%$. (CBN, 2017).

\subsection{Objectives \\ - To determine whether interest rate has a positive or negative relationship with agricultural output. \\ - To ascertain the significance of this relationship.}

\section{Theoretical Framework}

The classical theory of interest rate sees interest as what equilibrates savings and investments. A self-adjusting market that relies on a basic relationship. One of such relationships is between interest rate and investment such that when interest is low, there is a greater opportunity for profit and as such investors will pounce on this opportunity to borrow at low interest rates and invest. Conversely, when interest rates are high or higher than profit margins, there is little or no opportunity to make profit so investors will borrow less. (Brigo \& Mercurio, 2007) 


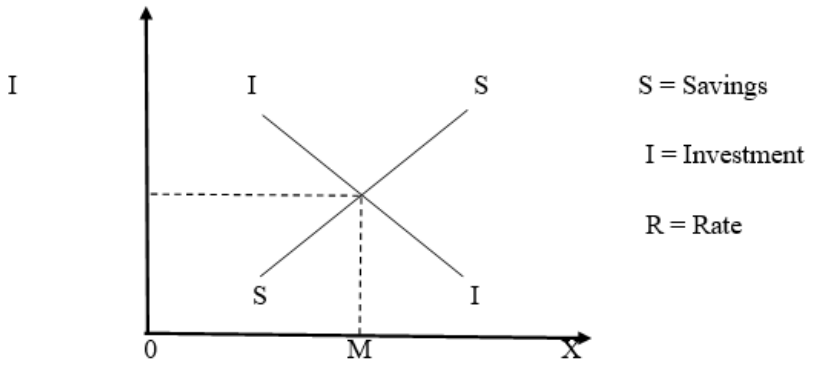

Figure 2: Classical Theory of Interest

Similarly, according to Keynes' (1936) general theory, one of the ways to stimulate growth in an economy is through monetary policy in the form of lowering interest rates as this would lead to greater demand in the form of investments. Keynes like classical economists believed lower interest rates give more motive for capitalists. However, unlike the classical economists though believing in this relationship further see the market as self-adjusting and advice against tampering with these market forces, Keynes encouraged such intervention to boost demand when the economy is in need of it. Using this logic, when governments lower interest rates, all sectors including the agricultural sector should see a boom in economic activities through greater investments.

Both theories stipulate that lower interest rates should increase output due to greater investments. Therefore, in applying it to our focus, this courtesy should logically extend to the agricultural sector in an economy. Output in this sector should increase when interest rate is lower as there is greater investment in the sector.

Feasibility and accessibility of loans for investors is important because loans provide the main source of capital for businesses which drive every sector in an economy. Ruete (2015) stipulated that access to finance is crucial for the agricultural sector of developing countries but was difficult because entrepreneurs and small farmers have not properly been drawn into the financial system. She noted a positive relationship between the levels of development of agricultural financial markets to the development of the agricultural sector.

\section{Literature Review}

3.1 Nigeria

Onyishi et al (2015) examined the impact of interest rate reforms on Agricultural growth and finance in Nigeria from between 1970 and 2011. The underlying theory behind the study highlighted that deregulation of interest rate would increase inflow of resources into the agricultural sector and propel its contribution to national development. They uncovered that interest rate deregulation did have a positive and significant effect on agricultural growth. Furthermore, they found that average interest rate in addition to exchange rate of the naira influenced the agricultural sectors fragment of the country's GDP and economy by long, medium and short term estimations while inflation had no significant effect. Noting the contradictory effect interest rate has on savings and investments where high interest rates increase supply of credit through savings but lowers investment, they stressed the need to find a proper rate that can counter or at least minimize this effect. They also advised the need for the state to give incentives for instance through lower interest rates for agricultural businesses in order to encourage both local and foreign investors to patronize this sector of the country.

Ehinomen \& Charles (2012) in exploring ways for sustainable ways for growth for Nigeria investigated the agricultural sector in the country and how monetary policy impacted its development. They found that interest rate had a monumental effect on agricultural development especially through stimulation of investments. Though lauding the efforts of the central bank, they reiterated the need for further policies to support gains and to punish banks and other financial institutions that do not conform to their policies.

Akpaeti (2013) sought to understand how investments in the agricultural sector in Nigeria responds to reforms in financial institutions between 1970 and 2009. The study found that these reforms significantly impacted investments in the agricultural sector positively. One of the recommended reforms by this research was for the state to introduce interest rate reforms as such an incentive would encourage investments in this sector. Furthermore, the economy should be liberalized as this would vitalize the business sector as a whole and this will in turn create a sustainable financial sector that can help improve the agricultural sector.

Kareem et al (2013) explored macroeconomic factors to examine which had the most effect on agricultural output. They detected interest rate as one of the factors that had a significant effect on agricultural output.

Ajudua et al (2015) examined the effects of monetary policy in the form interest rate, inflation rate, money supply and monetary policy rate on Nigerias agricultural sector between 1986 and 2013 Using OLS regression, they found a strong relationship between these facets of monetary policy and the agricultural sector. Studying interest rate, the model predicted that a $1 \%$ increase in interest rate would cause a $0.032 \%$ fall in agricultural growth while a $1 \%$ increase in monetary policy rate will cause a $0.0036 \%$ contraction of this sector. They also concluded that making low interest rates available to farmers would be a sure fire boosting agricultural productivity in the country.

Amassoma et al (2011) delved into interest rate and lending rate deregulation would affect agricultural output. Though finding a correlation between interest rate and agricultural output, this correlation was insignificant concluding that mandatory interest rate policy by the government hinders the lending efficiency of banks as they are forced to rely on first rate borrowers. Therefore, this study called for a total deregulation of interest rates as this would make more funds available for loans. Furthermore, it advocated for more complimentary lending and borrowing rates and for state focus on making agricultural credit more available to competent people after proper screening and scrutiny. 
Similarly, Ezeanyi (2014) assessed the role of interest rate deregulation on agricultural yield in Nigeria between 1986 and 2010. However, unlike previous research, this study found interest rate to play an insignificant role on the agricultural sector.

\subsection{South Africa}

A study by the economic research division of the South African department of agriculture, forestry and fisheries (2010) sort to explain why low interest rates have not curbed farm debt but rather increased them. They found that this was due to the increasing prices of farming equipment and input even with low agricultural product prices which forced farmers to seek more loans in order to get required capital for production. They also found that farmers were being charged higher interest rates than normal interest rates and this may have been a contributing factor.

\subsection{US, France and Brazil}

Westercamp et al (2015) assessed agricultural credit in terms of the usage of interest subsidies in France, Brazil and the US. The study concluded that given the right conditions, interest rate is a useful device to back agriculture. However, the study recommended that this should be under adequate management and supervision to ensure objectives aren't strayed from though this may prove costly for the system. In order for this to be possible, a country must seek to develop a reliable financial system (both private and public intermediaries that meet specifications included) which they should use to distribute these loans to farmers and investors who should also be guided on how to expend these loans shrewdly.

\subsection{Ukraine}

Tarasov (2013) examined how interest rate affected decisions to insure agricultural produce. He found that interest rate had a significant effect on insurance cash flow on agricultural production. He further stipulated that higher interest rates will give producers less incentive to ensure in emerging economies, especially those of Eastern Europe.

\section{Research Hypothesis}

Hypothesis 1

$\mathrm{H}_{0}$ There is no significant relationship between interest rate and crop production.

$\mathrm{H}_{1}$ There is a significant relationship between interest rate and crop production

Hypothesis 2

$\mathrm{H}_{0}$ There is no significant relationship between interest rate and Livestock farming.

$\mathrm{H}_{1}$ There is a significant relationship between interest rate and livestock farming.

Hypothesis 3

$\mathrm{H}_{0}$ There is no significant relationship between interest rate and forestry.

$\mathrm{H}_{1}$ There is a significant relationship between interest rate and forestry.

Hypothesis 4

$\mathrm{H}_{0}$ There is no significant relationship between interest rate and fishing.

$\mathrm{H}_{1}$ There is a significant relationship between interest rate and fishing.

Hypothesis 5

$\mathrm{H}_{0}$ There is no significant relationship between interest rate and agriculture.

$\mathrm{H}_{1}$ There is a significant relationship between interest rate and agriculture.

\section{Data Collection}

Lending rates for period used was sourced from the International Monetary Fund (IMF) and agricultural sector activity include figures for crops, livestock, forestry, and fishing specifically were sourced from the Central Bank of Nigeria (CBN).

\subsection{Variables and Data Source}

\begin{tabular}{|l|l|}
\hline Variable & Source \\
\hline Crops (Real, Nominal) & Central Bank of Nigeria (CBN) \\
\hline Livestock (Real, Nominal) & Central Bank of Nigeria (CBN) \\
\hline Forestry (Real, Nominal) & Central Bank of Nigeria (CBN) \\
\hline Fishing (Real, Nominal) & Central Bank of Nigeria (CBN) \\
\hline Agriculture (Real, Nominal) & Central Bank of Nigeria (CBN) \\
\hline Lending Interest Rates & International Monetary Fund (IMF) \\
\hline
\end{tabular}

Table 1: Sources

5.2 Tests

\begin{tabular}{|l|l|}
\hline Test & Purpose \\
\hline Pearson Correlation Analysis & $\begin{array}{l}\text { This is carried out to determine find the relationship between variables } \\
\text { and how a variable (independent variable) affects another variable } \\
\text { (dependent variable). Interest rate was used as independent variable and } \\
\text { agricultural sector activity was used as dependent variable. }\end{array}$ \\
\hline
\end{tabular}

Table 2: Tests

Testing Hypothesis 1

$\mathrm{H}_{0}$ There is no significant relationship between interest rate and crop production.

$\mathrm{H}_{1}$ There is a significant relationship between interest rate and crop production. 


\begin{tabular}{|ll|l|l|}
\hline \multicolumn{2}{|l|}{ Correlations } & \multicolumn{2}{l|}{} \\
\hline & & Interest Rate & Crops \\
\hline Interest Rate & Pearson Correlation & 1 & $-.718^{* *}$ \\
& Sig. (2-tailed) & & .001 \\
& $\mathrm{~N}$ & 18 & 18 \\
\hline Crops & Pearson Correlation & $-.718^{* *}$ & 1 \\
& Sig. (2-tailed) & .001 & \\
& $\mathrm{~N}$ & 18 & 18 \\
\hline
\end{tabular}

**. Correlation is significant at the 0.01 level (2-tailed).

Table 3: Correlation 1.1

Correlations

\begin{tabular}{|ll|l|l|}
\hline & & Interest Rate & Real Crops \\
\hline Interest Rate & Pearson Correlation & 1 & $-.769^{* *}$ \\
& Sig. (2-tailed) & & .000 \\
& $\mathrm{~N}$ & 18 & 18 \\
\hline Real Crops & Pearson Correlation & $-.769^{* *}$ & 1 \\
& Sig. (2-tailed) & .000 & \\
& $\mathrm{~N}$ & 18 & 18 \\
\hline
\end{tabular}

**. Correlation is significant at the 0.01 level (2-tailed).

Table 4: Correlation 1.2

Interest rate is found to have a strong significant negative relationship with crops in nominal $(\mathrm{p}=-.718, \mathrm{r}=.001)$ and reals terms $(\mathrm{p}=-.769, \mathrm{r}=.000)$.

Based on this, there is sufficient evidence to reject $\mathrm{H}_{0}$ in favor of $\mathrm{H}_{1}$.

Testing Hypothesis 2

$\mathrm{H}_{0}$ There is no significant relationship between interest rate and Livestock.

$\mathrm{H}_{1}$ There is a significant relationship between interest rate and Livestock.

Correlations

\begin{tabular}{|ll|l|l|}
\hline & Interest Rate & Livestock \\
\hline Interest Rate & Pearson Correlation & 1 & $-.682^{* *}$ \\
& Sig. (2-tailed) & & .002 \\
& $\mathrm{~N}$ & 18 & 18 \\
\hline Livestock & Pearson Correlation & $-.682^{* *}$ & 1 \\
& Sig. (2-tailed) & .002 & \\
& $\mathrm{~N}$ & 18 & 18 \\
\hline
\end{tabular}

**. Correlation is significant at the 0.01 level (2-tailed).

Table 5: Correlation 2.1

\section{Correlations}

\begin{tabular}{|ll|l|l|}
\hline & Interest Rate & Real Livestock \\
\hline Interest Rate & Pearson Correlation & 1 & $-.757^{* *}$ \\
& Sig. (2-tailed) & 18 & .000 \\
& $\mathrm{~N}$ & 18 & 18 \\
\hline Real Livestock & Pearson Correlation & $-.757^{* *}$ & 1 \\
& Sig. (2-tailed) & .000 & \\
& $\mathrm{~N}$ & 18 & 18 \\
\hline
\end{tabular}

**. Correlation is significant at the 0.01 level (2-tailed).

Table 6: Correlation 2.2

A significant strong negative relationship was found between interest rate and nominal livestock $(p=-.682, r=.002)$. The same relationship was confirmed using values for real livestock $(\mathrm{p}=-.757, \mathrm{r}=.000)$.

Based on this, there is sufficient evidence to reject $\mathrm{H}_{0}$ in favor of $\mathrm{H}_{1}$.

Testing Hypothesis 3

$\mathrm{H}_{0}$ There is no significant relationship between interest rate and Forestry.

$\mathrm{H}_{1}$ There is a significant relationship between interest rate and Forestry. 


\begin{tabular}{|ll|l|l|}
\hline \multicolumn{2}{|c|}{ Correlations } & & \\
\hline & & Interest Rate & Forestry \\
\hline Interest Rate & Pearson Correlation & 1 & $-.714^{* *}$ \\
& Sig. (2-tailed) & & .001 \\
& $\mathrm{~N}$ & 18 & 18 \\
\hline Forestry & Pearson Correlation & $-.714^{* *}$ & 1 \\
& Sig. (2-tailed) & .001 & 18 \\
& $\mathrm{~N}$ & 18 & \\
\hline
\end{tabular}

**. Correlation is significant at the 0.01 level (2-tailed).

Table 7: Correlation 3.1

\section{Correlations}

\begin{tabular}{|ll|l|l|}
\hline & & Interest Rate & Real Forestry \\
\hline Interest Rate & Pearson Correlation & 1 & $-.724^{* *}$ \\
& Sig. (2-tailed) & & .001 \\
& $\mathrm{~N}$ & 18 & 18 \\
\hline Real Forestry & Pearson Correlation & $-.724^{* *}$ & 1 \\
& Sig. (2-tailed) & .001 & \\
& $\mathrm{~N}$ & 18 & 18 \\
\hline
\end{tabular}

**. Correlation is significant at the 0.01 level (2-tailed).

\section{Table 8: Correlation 3.2}

Correlation tests found a significant strong negative correlation with interest rate and nominal forestry $(\mathrm{p}=-.714, \mathrm{r}=.001)$, and interest rate and real forestry $(\mathrm{p}=-.724, \mathrm{r}=.001)$.

Based on this, there is sufficient evidence to reject $\mathrm{H}_{0}$ in favor of $\mathrm{H}_{1}$.

Testing Hypothesis 4

$\mathrm{H}_{0}$ There is no significant relationship between interest rate and Fishing.

$\mathrm{H}_{1}$ There is a significant relationship between interest rate and Fishing.

\begin{tabular}{|ll|l|l|}
\hline & & Interest Rate & Fishing \\
\hline Interest Rate & Pearson Correlation & 1 & $-.667^{* *}$ \\
& Sig. (2-tailed) & & .003 \\
& $\mathrm{~N}$ & 18 & 18 \\
\hline Fishing & Pearson Correlation & $-.667^{* *}$ & 1 \\
& Sig. (2-tailed) & .003 & \\
& $\mathrm{~N}$ & 18 & 18 \\
\hline
\end{tabular}

**. Correlation is significant at the 0.01 level (2-tailed).

Table 9: Correlation 4.1

Correlations

\begin{tabular}{|ll|l|l|}
\hline & Interest Rate & Real Fishing \\
\hline Interest Rate & Pearson Correlation & 1 & $-.700^{* *}$ \\
& Sig. (2-tailed) & & .001 \\
& $\mathrm{~N}$ & 18 & 18 \\
\hline Real Fishing & Pearson Correlation & $-.700^{* *}$ & 1 \\
& Sig. (2-tailed) & .001 & \\
& $\mathrm{~N}$ & 18 & 18 \\
\hline
\end{tabular}

**. Correlation is significant at the 0.01 level (2-tailed).

Table 10: Correlation 4.2

Tests show a significant strong negative correlation between interest rate and fishing in nominal $(\mathrm{p}=-.667, \mathrm{r}=.003)$ and real terms $(\mathrm{p}=-.700, \mathrm{r}=.001)$.

Based on this, there is sufficient evidence to reject $\mathrm{H}_{0}$ in favor of $\mathrm{H}_{1}$.

Testing Hypothesis 5

$\mathrm{H}_{0}$ There is no significant relationship between interest rate and Agriculture.

$\mathrm{H}_{1}$ There is a significant relationship between interest rate and Agriculture. 


Correlations
\begin{tabular}{|ll|l|l|}
\hline & & \multicolumn{2}{l|}{ Agriculture } \\
\hline Interest Rate & Pearson Correlation & Interest Rate & $-.715^{* *}$ \\
& Sig. (2-tailed) & 1 & .001 \\
& $\mathrm{~N}$ & 18 & 18 \\
\hline Agriculture & Pearson Correlation & $-.715^{* *}$ & 1 \\
& Sig. (2-tailed) & .001 & 18 \\
& $\mathrm{~N}$ & 18 & \\
\hline
\end{tabular}

**. Correlation is significant at the 0.01 level (2-tailed).

Table 11: Correlation 5.1

\section{Correlations}

\begin{tabular}{|ll|l|l|}
\hline & & Interest Rate & Real Agriculture \\
\hline Interest Rate & Pearson Correlation & 1 & $-.768^{* *}$ \\
& Sig. (2-tailed) & & .000 \\
& $\mathrm{~N}$ & 18 & 18 \\
\hline Real Agriculture & Pearson Correlation & $-.768^{* *}$ & 1 \\
& Sig. (2-tailed) & .000 & \\
& $\mathrm{~N}$ & 18 & 18 \\
\hline
\end{tabular}

**. Correlation is significant at the 0.01 level (2-tailed).

Table 12: Correlation 5.2

Subsequently, a Pearson's correlation test was run to determine the overall relationship between interest rate and agriculture. Results show a strong negative relationship between interest rate and nominal agriculture $(p=-.715, r=.001)$, and between interest rate and real agriculture $(\mathrm{p}=-.768, \mathrm{r}=.000)$ and is significant at a two tailed 0.01 level.

Based on this, there is sufficient evidence to reject $\mathrm{H}_{0}$ in favor of $\mathrm{H}_{1}$.

5.3 Summary of results

\begin{tabular}{|l|l|l|l|l|l|}
\hline Hypothesis & $\begin{array}{l}\text { Independent } \\
\text { Variable }\end{array}$ & $\begin{array}{l}\text { Dependent } \\
\text { Variable }\end{array}$ & Relationship & Significance & $\begin{array}{l}\text { Null } \\
\text { Hypothesis }\end{array}$ \\
\hline 1 & Interest Rate & Crops & Negative & Significant & Reject \\
\hline 2 & Interest Rate & Livestock & Negative & Significant & Reject \\
\hline 3 & Interest Rate & Forestry & Negative & Significant & Reject \\
\hline 5 & Interest Rate & Fishing & Negative & Significant & Reject \\
\hline
\end{tabular}

Table 13: Results

\section{Conclusions and Recommendations}

In line with the theoretical framework, the negative relationship shown by tests between interest rate and agricultural activity confirmed that lower interest rates encouraged movement in this sector and higher interest rates correlated with stunted growth in the sector. This relationship was also found to be significant.

Currently interest rates and monetary policy in general isn't being pursued as a means of jolting productivity in all sectors of the country and interest rates remain relatively high. But evidently it is an effective way of achieving this goal and not only should lower interest rates be offered to investors and farmers in the agricultural industry, cost free loans should also be considered. This along with more spending will undoubtedly produce the desired effects and lead to optimum productivity.

To enhance the effect of lower interest rates, the government should also consider pursuing a flexible exchange rate as this is best suited monetary policy given capital mobility as lower exchange rates results in capital outflow, weakening the currency and making local products cheaper. This will stimulate production in the local industries in the country.

\section{Reference List}

Ajudua Emmanuel, I., JP, D.O. and Okonkwo, O.N., 2015, A Review of Monetary Policy and the Nigerian Agricultural Sector Performance.

Akpaeti, A.J., 2013. Does Financial Sector Reforms Affect Agricultural Investments in Nigeria? A Cointegration and VAR Approach. International Journal of Food and Agricultural Economics, 1(2), pp.13-28.

Amassoma, J.D., Nwosa, P.I. and Ofere, A.F., 2011. The nexus of interest rate deregulation, lending rate and agricultural productivity in Nigeria. Current Research Journal of Economic Theory, 3(2), pp.53-61.

Brigo, D. and Mercurio, F., 2007. Interest rate models-theory and practice: with smile, inflation and credit. Springer Science \& Business Media.

Central Bank of Nigeria, 2017, "Monetary Policy, Decisions". Available at: http://www.cbn.gov.ng/monetaryPolicy/decisions.asp

Ehinomen, C \& Charles, AC 2012, "Impact of Monetary Policy on Agricultural Development in Nigeria.", IOSR Journal of Humanities and Social Sciences. vol. 5, no. 5, pp. 13-25.

Ezeanyi, CI, 2014, “An Assessment of the Impact of Interest Rate Deregulation in Enhancing Agricultural Productivity in 
Nigeria”, Journal of Economics and Sustainable Development”. Vol. 5, no.8.

IMF International Financial Statistics (IFS)

Kareem, R.O., Bakare, H.A., Raheem, K.A., Ologunla, S.E., Alawode, O.O. and Ademoyewa, G.R., 2013. Analysis of Factors Influencing Agricultural Output in Nigeria: Macroeconomics Perspectives. American Journal of Business, Economics and Management, 1(1), pp.9-15.

Keynes, J.M., 1937. The general theory of employment. The quarterly journal of economics.

Onyishi, L.O., Arene, C.J. and Ifiorah, C.M., 2015. Impact of interest rate reform on agricultural finance and growth in Nigeria. Russian Journal of Agricultural and Socio-Economic Sciences, 37(1).

Ruete, M., 2015. Financing for Agriculture: How to boost opportunities in developing countries. Unvestment in Agriculture, Policy Brief, 3.

Tarasov, A., 2013. Impact of interest rates on the decision to insure in agricultural production. Studies in Agricultural Economics, 115(1).

Westercamp, C., Nouri, M. and Oertel, A., 2015. Agricultural Credit, Assessing the Use of Interest Rate Subsidies. Agence française de développement. 